\title{
The economic cost of extreme and severe droughts in soybean production in Argentina
}

\author{
El costo económico de eventos severos y extremos de sequía en la producción \\ de soya Argentina
}

\author{
Esteban Otto Thomasz, Ana Silvia Vilker, Gonzalo Rondinone*
}

Universidad de Buenos Aires, Argentina

Received 14 February 2017; accepted 8 August 2018

Available online 20 November 2018

\begin{abstract}
The objective of this study is to estimate the economic cost of droughts on soybean production in Argentina. By means of a linear model, extreme negative deviations in soybean yields during 1970-2016 are identified. It was found that in all cases extreme deviations in yields are related to severe and extreme droughts according to the palmer index. Constructing a counterfactual scenario and by means of the international soybean price, the economic loss is valued. It was found that in the aggregated sample the income loss due to drought events was of $\$ 8.046$ million in dollars of 2016 , equivalent to $22 \%$ of Argentinean international reserves of that year.
\end{abstract}

JEL codes: Q1, Q5, O13

Keywords: Soybean; Drought; Palmer Index.

\footnotetext{
*Corresponding author.

E-mail address: gonzalorondinone@economicas.uba.ar (G. Rondinone)

Peer Review under the responsibility of Universidad Nacional Autónoma de México.
} 


\section{Resumen}

El objetivo de este estudio es estimar el costo económico de los eventos de sequía para la producción de soja en Argentina. Mediante el uso de un modelo lineal se identifican eventos negativos extremos en los rendimientos de soja para el período 1970-2016. Se encuentra que todos los casos de desvíos extremos están relacionados con eventos de sequía acorde al índice de Palmer. Se reconstruye un escenario contrafáctico de rendimientos y valorizando mediante los precios internacionales del poroto de soya se estima el costo económico. Se encuentra que en el agregado de la muestra relevada la pérdida económica debido a eventos de sequía fue de 8.046 millones de dólares de 2016, equivalentes al $22 \%$ de las reservas internacionales de Argentina para ese año.

Códigos JEL: Q1, Q5, O13

Palabras claves: Soja; Sequía; Índice Palmer.

\section{Introduction}

Climate change related risks are increasing rapidly with highly vulnerable communities living in different conditions: cities, countryside and informal settlements. The likely direct impacts of climate change and climate variability include extreme precipitation, heat stress, pluvial and fluvial flooding, landslides, drought, increased aridity, and water scarcity with widespread indirect impacts on people, economies and ecosystems (Revi et al, 2014).

Climate change is expected to have severe effects on the populations of developing countries because many of them depend heavily on agriculture for income, have large impoverished rural populations which rely on agriculture for subsistence, and are financially and technically least equipped to adapt to changing conditions (Seaman et al, 2014). Therefore, planning measures to support adaptation to reduce the impact of climate change on poverty and food security requires methods of identifying vulnerable regions at national and local levels.

The Intergovernmental Panel on Climate Change (IPCC) expects that climate change will have major impacts in the near-term based on extreme precipitation and drought in developing countries. This will lead to shifts in the production areas of food and non-food crops and will have major impacts on food security and agricultural incomes, with a disproportionate impact on the welfare of the rural poor (IPCC, 2015).

However, adaptation and mitigation policies remain scarce in middle-income countries. Finite resources and technological capacity restrict the ability of adaptation strategies in social systems, primarily in developing countries (Kates et al, 2012; Moser and Ekstrom, 2010).

In the particular case of Argentina, since 1960 there was a remarkable increase in precipitation over most of the subtropical region of the country. This has favored the increase in crops' yields and also the expansion of crop lands into semiarid regions (Barros, 2015). This effect, among other economic factors such as the Asian miracle and increase in technology (Massot, 2016), made agricultural exports reach a share of 55\% of total exports for the period 2003-2016. Soybean, soybean oil and soybean meal contributed with $23 \%$ to the total valued exported in that period.

Despite research has been done in estimating crop's reaction to different scenarios of increase of $\mathrm{CO} 2$ emissions, there is no research that take into account climate variability in 
the short term at a nationwide scale. The valuation of current and medium-term losses is a must to communicate the need of an adaptation strategy for the most vulnerable countries like Argentina.

Therefore, the objective of this study is to provide an estimate of income losses in soybean production in Argentina due to climate variability. These valuations may provide important information to plan adaptation strategies for a current problem, which should be taken by developing countries highly reliant on agricultural exports like the case studied. The objective of the study is to provide a general estimation of the magnitude of the economic loss to determine if the level of impact is local, regional or macroeconomic; and therefore discuss which kind of adaptation measures should be proposed.

The first section of this work summarizes different approaches to estimate crops reaction to weather events. The second section presents the selected model and data. Section three synthesizes results and section four and five presents further discussion and some concluding remarks.

\section{Theoretical framework}

When addressing the problem of impact valuation of climate change or climate risk, several problems arise: scale, kind of impact to measure, valuation methodology, prices projection and information availability.

Regarding the scale, valuation results will be totally different if the problem is analyzed globally, nationwide, or at a regional/local level. Studies at a global scale, they analyze impacts of a certain trend-global warming- or shock -drought or excessive rainfall- across countries and in the global economy. For instance, Burke et al (2015) conclude that unmitigated warming is expected to reshape the global economy by reducing average global incomes roughly $23 \%$ by 2100 and widening global income inequality due to different impacts between agricultural and industrialized countries with non-linear effect of temperature on economic production, relative to scenarios without climate change. As for shocks at a global scale, Cashin, Mohaddes and Raissi (2014) analyze the international macroeconomic transmission of El Niño weather shocks, concluding that the economic consequences differ across countries, considering variables such as economic activity or inflation.

Regarding nationwide approach (Aaheim, 2012; CIER, 2007; CEPAL, 2010; DNP BID, 2014; CEPAL, 2014), most value the impact over economic sectors (agriculture, fishery, forestry, transport, energy and water resources) and then summarized them into GDP estimates, in some cases through a general equilibrium macroeconomic model. However, this approach is related to $\mathrm{CO} 2$ emissions scenario and do not take into account climate variability ${ }^{2}$. Also, linkages between sectors -such as the relation between water resources, energy and agricultureare not monetary valued. Finally, as impacts of climate change are experienced locally (Carter et al, 2014), local scale approach has been more deeply studied by selecting a specific area of agricultural production or a field.

Therefore, selecting the scale will somehow define the scope of the problem to be analyzed, such as food security, rising prices or production loss. Regarding economic impact, it might be focalized in income or profit, or in the effect on prices. Therefore, valuation methodology will

\footnotetext{
${ }^{2}$ There are examples of nationwide studies that look at climate variability and do not strictly focus on CO2 emissions. For example https://riskybusiness.org/report/national/
} 
depend on scale and type of impact and can range from simple approaches (macroeconomic sensitivity) to more sophisticated cross sectional statistical methods or time series analysis (sensibility models, Ricardian models, loss function models, etc.).

However, sensibility estimation models require a large amount of information, and climate information availability is scarce in underdeveloped countries. Nevertheless, according to the data-base study performed by Gall (2015), loss estimates provide crucial, although incomplete, data for estudying the relationship between climate change and its effects on climate-sensitive hazards as well as loss and damage.

Lastly, when facing economic valuation, prices are not only a key element to be taken into account but also one of the most difficult variables to forecast. This is because all effects (economic, political, social, climatic and expectations) are somehow expressed on current prices. Isolating global commodities prices fluctuations due to specific climate events require a deep econometric analysis. Different approaches to evaluate impact on commodity prices can be consulted in Cashin et al (2014), Arteaga et al (2013) and Thomasz et al (2016).

This research studies the economic impact on the agricultural sector. Therefore, some of the most common and widely used approaches in agriculture such as, the agronomic, Ricardian and yields variability approaches are summarized below.

\section{Agronomic approach}

The agronomic approach estimates changes in yields due to technology, soil quality and of course climate events, among many other relevant variables. It is widely used in several studies, such as Lobell and Burke (2010), Rahman (2005), Paltasingh et al (2012), Chimeli et al (2008). The approach estimates sensibility coefficients through different methods -mainly least squares- in cross section data for different areas, or in a time series within one specific area. A general equation for this approach is:

$$
Q_{r t}=\beta_{0}+\beta_{1} A_{r t}+\sum \beta_{i} V T_{r t} \sum \beta_{j} V C_{r t}+\sum \beta_{k} V S+\mu_{t}
$$

Where,

$Q_{r t}$ : crop yield in a predefined county or region and for a certain time period (Paltasingh et al, 2012; Loyola et al, 2010; Lobell, 2010; Tannura et al, 2008). Ordaz et al (2010) estimates this production function using as dependent variable aggregate production indexes instead of a specific crop.

$A_{r t}$ : area harvest for crop in county or region; $V T_{r t}$ : technological variables such as soil quality, seed genetics, and producer-level management techniques; $V C_{r t}$ climatic variables such as average and maximum temperature, accumulated rainfall; VS socioeconomic variables such as total population, total economically active population, and rural economically active population.

Different studies use a different set of variables to isolate the impact of climate variables over crop's yields. For instance, Ordaz et al (2010) use socioeconomic data as a control variable because in their study agricultural production is labor intensive. On the other hand, impact of technology was incorporated by Tannura et al (2008) in a study of soybean and corn yields in Illinois, Indiana and Iowa. 
This approach can be accurate to estimate the sensitivity of yields to climate variables. However, it does not provide economic estimations of losses produced by weather events and does not incorporate climate variability: changes through the years of the estimated coefficient are usually associated to climate change. Finally, it requires an extensive data set at local scales.

\section{The hedonic approach}

The hedonic approach, also called Ricardian method, is a popular method to estimate the effects of climate change over land value. It can be used to estimate the effects on the rent of land and also over agricultures benefits, according to different variations of the model.

In a perfect competitive market, land value equals present value of future profits generated by land's production. Land income can be represented as follows:

$$
I=\sum p_{i} Q_{i}(t, s, c, x)-\sum w_{x} x
$$

Where $p_{i}$ is the crop`s price, $Q_{i}$ the production level, $x$ represents input and $w_{x}$ is price of input x. Production level depends on technological (t), socioeconomic (s) and climatic variables (c). Producers choose $\mathrm{x}$ in order to maximize net income. Maximum net income is given by:

$$
I^{*}=f\left(p_{i}, t, s, c, w_{x}\right)
$$

With the result of equation 3, land value is calculated as the present value of future income: $\int_{0}^{\infty} I^{*} e^{-r t}(4)$, where $e^{-r t}$ is the continuos actualization factor for interest rate $r$ and time $t$. According to Seo et al (2008), equation 4 can be econometrically represented as follows:

$$
L V_{t}=\beta_{0}+\sum \beta_{i} V T_{r t} \sum \beta_{j} V C_{r t}+\sum \beta_{k} V S+\mu_{t}
$$

Where $L V_{t}$ is land value, and $V T_{r t}, V C_{r t}$ and $V S_{r t}$ are vectors of technologycal, climatic and socioeconomical variables $\beta_{0}$ is the intercept, $\beta_{\mathrm{i}, \mathrm{j}}$ the parameters coefficients and $\mu_{t}$ the stochastic error.

Deschenes et al (2007) employed the Ricardian approach to study the economic impact of climate change over the main crops produced by the USA. They modified the model to have profits instead land value as dependent variable:

$$
P_{r t}=\beta_{0}+\sum \beta_{i} V C_{r t}+\sum \beta_{j} V R+\alpha_{r}+\mu_{t}
$$

Where are the profits of a region for year $t$, is a vector of climatic variables ${ }^{3}$ for the region for year $t$, is a vector of relevant variables in the determination of land value ${ }^{4}$. Factor

\footnotetext{
${ }^{3}$ Temperature and rainfall of different months of the year.

${ }^{4}$ Number of farms, land in farms, total cropland, average value of land and buildings, average value of machines and equipment, annual financial information profits -profits per acre farm revenues, total farm expenses, total government payments- and measures of soil productivity $-\mathrm{K}$ Factor, slope length, fraction flood-prone, fraction sand, fraction clay, fraction irrigated, permeability, moisture capacity and wetlands-.
} 
represents the fixed effects for a region that absorbs every specific effect not observed by the dependent variable, is the intercept, the parameters coefficients and $\mu_{t}$ the stochastic error.

\section{Yield variability approach}

Another approach is the study of yields variability for a specific crop through a time series. Yields are affected by a complex combination of factors, such as weather, soil quality, seed genetics, and producer-level management techniques. However, despite this complexity, yields tend to show a general increase over time, which is commonly referred as the trend yield (Tanura et al, 2008).

The methodology estimates the yields` trend and study the deviation from it. Over empirical bases, it is then studied if those deviations can be explained by climate events.

There are many models to estimate the trend, such as linear and non-linear regression, polynomial adjustment, moving averages and local regression models. However, when studying crop yields` trends, the estimation of the trend is mainly done by a linear or log-linear model (Tanura and Irwin, 2015; Heinzenknecht, 2011; Beathgen, 2008; Thomasz et al, 2015). The equations of such models are:

Linear model: $\quad y_{t}=b_{0}+b_{1} x_{t}+\mu_{t}$

Log-linear model: $\quad y_{t}=b_{0}+b_{1} \ln \left(x_{t}\right)+\mu_{t}$

Where $y_{t}$ is the actual yield in year t, $x_{t}$ is the time period, $b_{0}$ is the intercept, $b_{1}$ is the trend coefficient, and $\mu_{\mathrm{t}}$ is the stochastic error. The absolute deviation from the trend is:

$$
d_{t=} y_{t}-\hat{y}_{t}
$$

Where $y_{t}$ is the actual yield in year $\mathrm{t}$, and $\hat{y}_{t}$ is the estimated trend in year $\mathrm{t}$. To measure the magnitude of each deviation, there are different approaches. One of them is to define exogenous scales in relative deviation (Heinzenknecht, 2011):

$$
R d_{t}=d_{t} / \hat{y}_{t}
$$

Where $R d_{t}$ is the relative deviation, $d_{t}$ is the absolute deviation and $\hat{y}_{t}$ is the estimated trend. Depending on the value of the relative deviation, current yields are classified into a linguistic scale of low, medium or high. The other approach is to classify in relation to the standard deviation of the sample (Beathgen, 2008):

$$
\begin{gathered}
d_{t}>-k \sigma \text { : non-extreme yields } \\
d_{t}<-k \sigma \text { : extreme yields }
\end{gathered}
$$

Where $k$ is the number of standard deviations that represent the limit from which yields are considered non-extreme from extreme. The selection of $k$ is empirical and depends on the distribution of the sample. 
Either classification allows identifying cases of yields` deviations that could potentially be explained by climate events. Having the potential cases, the following step it to analyze climate variables and determine if there was a climate shock in those years. Therefore, the approach identifies deviations that must be contrasted with a climate variable.

The methodology allows to easily identify extreme deviations of trended yields that are potentially explained by climate shocks. It is a simple approach which deals properly with scarce information. The trend estimation allows reconstructing a theoretical production for every year, in absence of climate variability. This means that the approach constructs a baseline or counterfactual scenario from which is possible to measure the production loss and consequently loss of income using different forecasts of prices.

\section{Approach, methodology and data}

\section{Approach}

The problem to be addressed in this work is the absence of a reliable and standardized model that can summarize a monetized income loss estimate in agricultural production due to climate events at a national/regional scale. The objective will be to provide estimates of income losses to determine the kind and scale of adaptation strategies. Therefore, this research starts with the valuation of past events, which could be taken into account to forecast into a mid-term future scenario.

The case to be studied is soybean production in the core area of Argentina, which represents $81 \%$ of national crop production and $77 \%$ of implanted area in 2016. It also represents an average of $23 \%$ of total value or exports between 2003-2016.

\section{Methodology}

To estimate income loss in soybean production the deviation from a linear trend model is used. The trend is adjusted through a linear model for two reasons. First, according to Irwin and Good (2015) log-linear model implies that the range of trend yield deviations in bushels should expand across time which clearly does not happen. It should also be noted that an important property of the linear trend model is that the percentage change in trend yields declines over time as the same bushel increase in trend yield is divided by a larger base. This is consistent with historical average soybean yields (Irwin and Good, 2015). Second, over empirical bases, in Thomasz et al (2015) was tested that the lineal model identifies all cases of draughts, while the log-linear model omits two cases.

Standard deviation of de-trended yields ${ }^{5}$ is calculated to identify extreme deviations. Extreme deviations are defined as those which exceed the limit of one standard deviation ${ }^{6}$. The aim of the study is to value production losses; therefore, only negative cases are analyzed.

The following step is to relate the extreme deviations in yields with climate events. In this work, the Palmer drought index will be used. Years of extreme deviations are compared to the index in the critical season of the crop. If drought levels are high, it is considered that the extreme deviation in yields were produced due to water shortage. Cases of extreme negative deviations which are not related to water shortage are not considered. In sum, any potential case has reach two attributes: be an extreme negative deviation from the yield`s trend and there has

\footnotetext{
${ }^{5}$ Absolute deviation of current yields from the trend.

${ }^{6}$ Empirical foundation is presented in Appendix B.
} 
to be a drought in the area measured by the Palmer Index. Thresholds of both attributes will be further detailed and discussed.

It must be pointed out that there might be cases of low yields not captured by the model because they do not cross the threshold. However, as it was mentioned, the methodology focus only in extreme events, therefore is expected to have very little omitted cases.

When a case is identified, the production loss is estimated. To do this, the baseline scenario will be the yield trend plus one standard deviation, considering that within that interval fluctuations can be considered as non-extreme event. The quantity loss is multiplied by the price estimate to value the loss of income. Regarding price estimate, international soybean price will be used. We assume for our valuation that international prices are not affected by Argentinian soybean production, which are mainly driven by United States physical stocks. In this case, an average price of the year will be used.

The estimation methodology is presented below:

A liner trend is estimated from observed yields, from where estimated yield is calculated for every year of the sample:

$$
\widehat{Y_{t}}=\beta_{0}+\beta_{1} * t
$$

Where, $\hat{y}_{t}$ is the estimated yield, $\beta_{0}$ is the intercept, $\beta_{1}$ is the linear trend coefficient and $t$ is time: between $\mathrm{t}=1$ and $\mathrm{t}=\mathrm{n}$.

The difference between the observed and estimated yield trend is calculated:

$$
Y_{t}^{s}=Y_{t}-\widehat{Y}_{t}
$$

This de-trended series represents potential effects of climate variability over trends. To set a limit to define normal from extreme yields, the standard deviation is calculated, $\sigma\left(Y_{t}^{s}\right)$. Therefore, value of $Y_{t}^{s}$ is classified as follows:

$$
Y_{t}^{s}= \begin{cases}1 & \text { if } Y_{t}^{s}<-\sigma Y_{t}^{s} \\ 0 & \text { if } Y_{t}^{s}>-\sigma Y_{t}^{s}\end{cases}
$$

Cases of $\sigma\left(Y_{t}^{s}\right)<-Y_{t}^{s}$ are potential cases of weather shocks affecting yields, which have to contrasted with a climatic variable. In the case studied, the value of the Palmer Drought Index is used. This negative deviations generated by climate effects are defined as $Y_{t}^{s} \boldsymbol{e}$

Estimation of yield loss is calculated as the difference of between $Y_{t}^{s} e$ and standard deviation limit. Therefore, the yield limit of defined as non-extreme variability is:

$$
Y_{t}^{n e}=Y_{t}-\left[Y_{t}^{s} e+\left(-\sigma Y_{t}^{s}\right)\right]
$$

The theoretical level of production, $Q_{t}^{n e}$, is reconstructed as:

$$
Q_{t}^{n e}=\frac{Y_{t}^{n e} * Q_{t}}{Y_{t}}
$$


Where $Q_{t}$ is the oberved production for every year of the sample. Production loss, $L Q_{t}$, is then calculated as:

$$
L Q_{t}=Q_{t}^{n e}-Q_{t}
$$

Finally, economic value loss, $V P Q_{t}$ is estimated with the international soybean price:

$$
V P Q_{t}=L Q_{t}^{*} P_{t}^{i}
$$

Where $P_{t}^{i}$ is the international soyucan piu « puriod $t$.

\section{The data}

The dataset consists of soybean production information of 80 counties of the three most important agricultural provinces of Argentina: Buenos Aires, Cordoba and Santa Fe. The sample represents a geographical area of 15 million harvested hectares' whose production is around 50 million tons of soybean, $81 \%$ of total soybean production of Argentina. For each county, the sample ranges from 1970 to 2015, with yearly information of area harvest, and production.

Regarding climate information, the Palmer drought index will be used. This index uses readily available temperature and precipitation data to estimate relative dryness. Only the values for the crop critical period will be used, which is mostly January in the case of soybean in the selected counties, according to the data of the Agricultural Risk Office (ORA) of Argentina.

\section{Results}

Results are summarized in this section. It must be pointed out that in almost all cases coefficient of the adjusted linear trend is statistically significant, information presented in annexes A. Also, limit selection of one standard deviation has an empirical foundation explained by empirical distribution. It was tested that setting a boundary of $2 \mathrm{SD}$ to define extreme weather cases doesn't identify cases that were effectively campaigns of severe drought. For example, in Province of Santa Fe a 2SD boundary doesn't detect extreme weather for 2012 and a 1 SD limit detects $56 \%$ of cases -these results are presented in annexes B-.

Methodology was applied to each one of the 80 counties of the sample, therefore providing 80 different regression models.

Despite sample starts in 1970, only results of the last 17 years are presented because of their economic significance. The following table summarizes the percentage of counties per province that experience extreme decreases in yields. 
Table 1

Percentage of counties per province with extreme decreases in yields

\begin{tabular}{lccccc}
\hline Campaign & Buenos Aires & Córdoba & Santa Fé & Entre Rios & La Pampa \\
\hline $2000 / 01$ & $4,2 \%$ & $0 \%$ & $0 \%$ & $0 \%$ & $0 \%$ \\
$2001 / 02$ & $0 \%$ & $0 \%$ & $0 \%$ & $0 \%$ & $7,7 \%$ \\
$2002 / 03$ & $4,2 \%$ & $5,9 \%$ & $0 \%$ & $0 \%$ & $0 \%$ \\
$2003 / 04$ & $1,1 \%$ & $35,3 \%$ & $11,1 \%$ & $37,5 \%$ & $0 \%$ \\
$2004 / 05$ & $0 \%$ & $5,9 \%$ & $5,6 \%$ & $0 \%$ & $0 \%$ \\
$2005 / 06$ & $1,1 \%$ & $0 \%$ & $11,1 \%$ & $18,8 \%$ & $15,4 \%$ \\
$2006 / 07$ & $1,1 \%$ & $0 \%$ & $0 \%$ & $0 \%$ & $7,7 \%$ \\
$2007 / 08$ & $6,3 \%$ & $0 \%$ & $16,7 \%$ & $0 \%$ & $0 \%$ \\
$2008 / 09$ & $91,6 \%$ & $47,1 \%$ & $77,8 \%$ & $100 \%$ & $84,6 \%$ \\
$2009 / 10$ & $4,2 \%$ & $5,9 \%$ & $0 \%$ & $0 \%$ & $0 \%$ \\
$2010 / 11$ & $6,3 \%$ & $11,8 \%$ & $0 \%$ & $0 \%$ & $38,5 \%$ \\
$2011 / 12$ & $8,4 \%$ & $64,7 \%$ & $44,4 \%$ & $0 \%$ & $0 \%$ \\
$2012 / 13$ & $1 \%$ & $23,5 \%$ & $0 \%$ & $0 \%$ & $30,8 \%$ \\
$2013 / 14$ & $11,2 \%$ & $0 \%$ & $5,6 \%$ & $0 \%$ & $0 \%$ \\
$2014 / 15$ & $0 \%$ & $0 \%$ & $0 \%$ & $0 \%$ & $0 \%$ \\
$2015 / 16$ & $1 \%$ & $0 \%$ & $50 \%$ & $62,5 \%$ & $0 \%$ \\
$2016 / 17$ & $2 \%$ & $0 \%$ & $0 \%$ & $0 \%$ & $0 \%$ \\
\hline
\end{tabular}

Source: own elaboration

In this introductory study we will focus on the cases of the 2008/09 and 2011/12 campaigns because they are consistent with severe or extreme cases of drought according to values of Palmer Drought index, as show in figure 1.
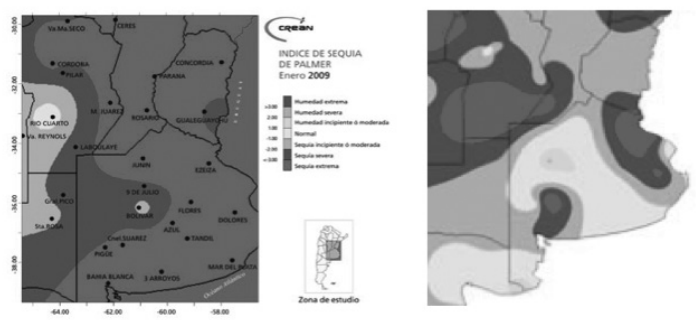

Figure 1. Palmer drought index January 2009 and 2012

Source: Centro de Relevamiento y Evaluación de Recursos Agrícolas y Naturales7

Tables 2, 3, 4, 5, 6, and 7 summarize income loss of soybean production at a county level in the Provinces of Buenos Aires, Cordoba, Santa Fe, Entre Rios y La Pampa valued in current dollars.

\footnotetext{
${ }^{7}$ http://www.crean.unc.edu.ar/index.html
} 
Table 2

Province of Buenos Aires

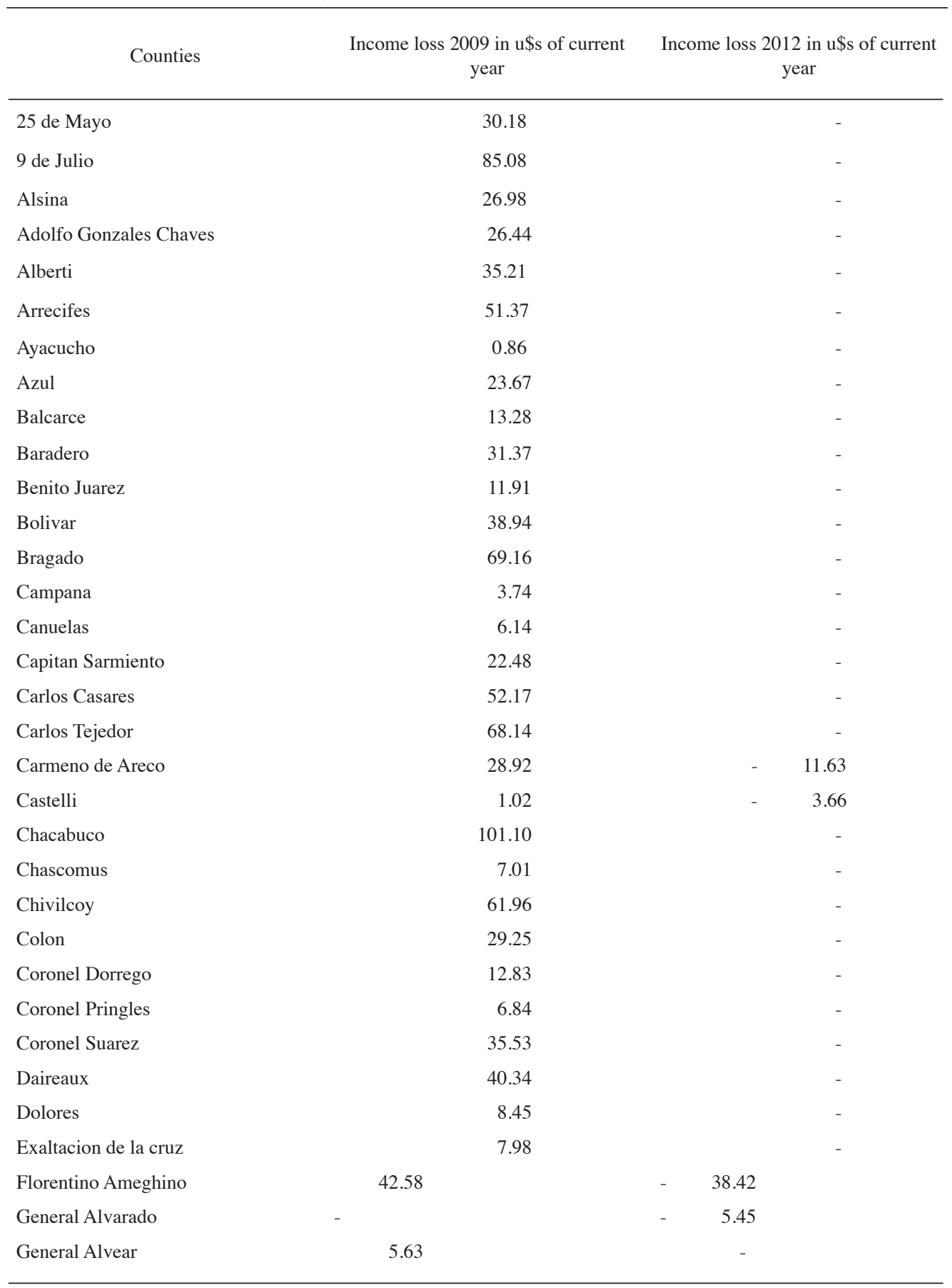




\begin{tabular}{|c|c|c|}
\hline General Arenales & 51.96 & - \\
\hline General Belgrano & 7.80 & - \\
\hline General Juan Madariaga & 2.98 & 3.27 \\
\hline General La Madrid & 7.72 & - \\
\hline General Las Heras & 3.23 & - \\
\hline General Pinto & 60.20 & 33.35 \\
\hline General Pueyrredon & 4.83 & - \\
\hline General Rodriguez & 1.55 & - \\
\hline General Viamonte & 42.09 & - \\
\hline General Villegas & 134.19 & $\begin{array}{l}-\quad 88.36\end{array}$ \\
\hline Guamini & 25.21 & - \\
\hline Hipolito Yrigoyen & 17.48 & - \\
\hline Junin & 99.41 & - \\
\hline Laprida & 5.18 & - \\
\hline Las Flores & 10.38 & - \\
\hline Leandro N. Alem & 65.80 & 33.81 \\
\hline Lincoln & 65.86 & $\begin{array}{l}-\quad 44.85 \\
-\quad 1\end{array}$ \\
\hline Loberia & 13.71 & - \\
\hline Lobos & 17.36 & - \\
\hline Lujan & 8.52 & 3.35 \\
\hline Maipu & 10.98 & - \\
\hline Marcos Paz & 5.25 & - \\
\hline Mercedes & 10.41 & - \\
\hline Monte & 9.74 & - \\
\hline Navarro & 13.56 & - \\
\hline Necochea & 15.15 & - \\
\hline Olavarria & 42.08 & - \\
\hline Patagones & 0.06 & - \\
\hline Pehuajo & 91.25 & - \\
\hline Pellegrini & 10.26 & - \\
\hline Pergamino & 96.40 & - \\
\hline Pilar & 1.24 & - \\
\hline Puan & 0.16 & - \\
\hline Ramallo & 43.58 & - \\
\hline Rauch & 34.66 & - \\
\hline Rivadavia & 101.26 & - \\
\hline Rojas & 92.89 & - \\
\hline Roque Perez & 18.31 & - \\
\hline
\end{tabular}




\begin{tabular}{lrc}
\hline Saavedra & 8.88 & - \\
Saladillo & 20.69 & - \\
Saliquelo & 8.70 & - \\
Salto & 52.79 & - \\
San Andres de Giles & 36.09 & 16.91 \\
San Antonio de Areco & 31.35 & - \\
San Cayetano & 23.23 & - \\
San Nicolas & 29.10 & - \\
San Pedro & 39.79 & - \\
Suipacha & 8.27 & 9.54 \\
Tapalque & 0.66 & - \\
Tornquist & 0.86 & - \\
Trenque Lauquen & 91.66 & - \\
Tres Arroyos & 26.62 & - \\
Tres Lomas & 11.59 & - \\
Villarino & 0.06 & - \\
Zarate & 18.61 & - \\
TOTAL & $2,638.22$ & \\
Sorre: & & - \\
\hline
\end{tabular}

Source: own elaboration

87 out of 95 counties of the Province of Buenos Aires suffered extreme decreases in yields in 2009, representing a total loss of $\mathrm{u} \$ \mathrm{~s} 2.638$ million valued in dollars of that year. However, only 8 out of 95 counties were severely affect by the 2012 drought, with an estimated loss of u\$s 292 million.

Table 3

Province of Córdoba

\begin{tabular}{|c|c|c|}
\hline Counties & $\begin{array}{c}\text { Income loss } 2009 \text { in } u \$ \text { s of current } \\
\text { year }\end{array}$ & $\begin{array}{c}\text { Income loss } 2012 \text { in } u \$ \text { s of current } \\
\text { year }\end{array}$ \\
\hline Marcos Juárez & 95.53 & 228.64 \\
\hline Unión & - & 221.32 \\
\hline Rio Cuarto & - & 180.35 \\
\hline San Justo & 86.60 & - \\
\hline General Roca & 131.81 & - \\
\hline Pres. R. Saenz Pena & 115.10 & 107.89 \\
\hline Rio Segundo & - & 234.34 \\
\hline Tercero Arriba & - & 117.20 \\
\hline Rio Primero & 99.33 & 134.78 \\
\hline Juárez Celman & 82.36 & 120.72 \\
\hline
\end{tabular}




\begin{tabular}{lcc}
\hline Colon & 27.53 & - \\
Rio Seco & 25.92 & - \\
Totoral & 47.24 & - \\
General San Martin & - & 129.28 \\
Tulumba & 35.98 & 40.41 \\
Calamuchita & - & 32.93 \\
TOTAL & 747,4 & $1.547,86$ \\
\hline Source: Own elaboration & &
\end{tabular}

The Province of Córdoba has a total of 17 counties. In this case, 8 counties have experience extreme decreases in yields in 2009 and 11 in 2012, with a total income loss of u\$s 747 million and $\mathrm{u} \$ \mathrm{~s} 1,547$ million, respectively.

Table 4

Province of Santa Fé

\begin{tabular}{lcc}
\hline Counties & Income loss 2009 in $\begin{array}{l}\$ \text { s of current year } \\
\text { Income }\end{array}$ & $\begin{array}{c}\text { loss } 2012 \text { in } u \$ s \text { of } \\
\text { current year }\end{array}$ \\
\hline General Lopez & 175.91 & 240.43 \\
Caseros & 68.60 & - \\
San Lorenzo & 68.17 & - \\
Rosario & 40.80 & 45.60 \\
San Justo & 45.34 & 31.05 \\
San Cristobal & 25.73 & 25.48 \\
General Obligado & 15.26 & 17.24 \\
9 de Julio & 29.30 & - \\
Belgrano & 41.86 & 111.69 \\
Castellanos & 52,75 & - \\
Constitución & 67.02 & - \\
Las Colonias & 73.52 & - \\
La Capital & 16.44 & 9.67 \\
Vera & 4.74 & 3.02 \\
San Javier & 1.94 & 484,18 \\
TOTAL & 727,37 & - \\
Soure: & &
\end{tabular}

Source: own elaboration

The Province of Santa Fe has 18 counties and 14 of them suffered extreme decreases in yields in 2009, representing a total loss of u\$s 727,3 million valued in dollars of that year. In 2012,8 out of 18 counties where severely affected, with an estimated loss of u $\$$ s 484,18 million. 
Table 5

Province of Entre Rios

\begin{tabular}{|c|c|c|}
\hline Counties & Income loss 2009 in $u \$$ s of current year & $\begin{array}{c}\text { Income loss } 2012 \text { in u } \$ \text { s of } \\
\text { current year }\end{array}$ \\
\hline Colon & 8.01 & - \\
\hline Concordia & 11.58 & - \\
\hline Diamante & 30.58 & - \\
\hline Federacion & 1.77 & - \\
\hline Federal & 8.62 & - \\
\hline Feliciano & 2.84 & - \\
\hline Gualeguay & 45.15 & - \\
\hline Gualeguaychu & 42.35 & - \\
\hline $\mathrm{La} \mathrm{Paz}$ & 24.57 & - \\
\hline Nogoya & 48.64 & - \\
\hline Paraná & 55.20 & - \\
\hline San Salvador & 8.46 & - \\
\hline Tala & 16.03 & - \\
\hline Uruguay & 37.53 & - \\
\hline Victoria & 55.33 & - \\
\hline Villaguay & 26.55 & - \\
\hline TOTAL & 423.21 & - \\
\hline
\end{tabular}

Source: own elaboration

Table 6

Province of La Pampa

Counties

Income loss 2009 in $u \$$ s of current year

Income loss 2012 in $u \$$ s of current year

\begin{tabular}{lcc}
\hline Atreuco & 4.27 & - \\
Capital & 2.38 & - \\
Catrilo & 6.68 & - \\
Chapaleufu & 30.33 & - \\
Conhelo & 3.37 & - \\
Maraco & 25.19 & - \\
Quemu Quemu & 10.30 & - \\
Rancul & 2.36 & - \\
Realico & 5.42 & - \\
Toay & 0.04 & - \\
Trenel & 2.33 & - \\
TOTAL & 92.68 & \\
\hline
\end{tabular}


Lastly, all Entre Rios counties suffered extreme events decrease in yields during 2008/09 campaign and 11 out of 13 counties of La Pampa exhibit the same pattern.

Table 7

Summary

\begin{tabular}{lll}
\hline \multicolumn{1}{c}{ Province } & \multicolumn{1}{c}{$\begin{array}{c}\text { Income loss 2009 in } \begin{array}{c}\text { year of current } \\
\text { year }\end{array} \\
\text { year }\end{array}$} \\
\hline Buenos Aires & $2,638.22$ & 292.61 \\
Córdoba & 747.40 & $1,547.86$ \\
Santa Fé & 727.37 & 484.18 \\
Entre Rios & 423.21 & - \\
La Pampa & 92.68 & - \\
\hline Total & $4,628.88$ & $2,324.65$ \\
Source: own elaboration & &
\end{tabular}

Therefore, the total income loss is estimated in u\$s 4.628 million for 2009 and $u \$ s 2.324$ for 2012, both figures in current dollars of each year. Calculating the total loss in dollars of 2016 by means of the international risk free rate $^{8}$, the final estimate is u $\$ \mathrm{~s} 8.046$ million. In relative terms, that amount represent $22 \%$ of international reserves of Argentinean Central Bank in 2016.

\section{Discussion}

The presented methodology works as follows, if an extreme deviation in yield is detected then the model compare against Palmer Drought Index in order to confirm or dismiss the extreme event. When both conditions are reached, the economic loss is calculated.

Therefore, the methodology only values extreme events, both in relation of the level of decrease in yields and the level of drought. This approach has proven to be robust enough to the objective of valuate the impact over a large geographical area with limited local information.

Regarding the utility of the results, the approach works well enough to conclude that severe and excessive droughts have a macroeconomic impact in the case of Argentina, in contrast with other countries where extreme droughts can have impacts over food security instead of macrofinancial effects. This shapes the kind of instruments that should be developed in the climate risk adaptation agenda.

Agricultural economic structure of soybean production is export-oriented and production downturns do not generate homeland problems of food security. Impact on producers might be high, but can be compensated with good weather years, as droughts have not been a trend ${ }^{9}$. However, macroeconomic and fiscal policy has been procyclical and trade balance highly dependent on commodities exports (Massot, 2016; Sorrentino and Thomasz, 2015). Therefore, macro-fiscal planning can benefit from setting public expenditure and reserves consumption

\footnotetext{
${ }^{8}$ The minimum possible interest rate is used as to set a conservative estimation, using as proxy the 10 years EEUU treasury bill yield.

${ }^{9}$ Mainly the opposite effect, an increase in the level of precipitations was observed.
} 
according to the structural behavior of cyclical resources (IMF, 2015; OCDE/CEPAL/CAF, 2015; Ardaz et al, 2015; Schaechter et al, 2012). Despite risk price in soybean has been studied in relation to shocks of American stocks and interest rate shocks (Thomasz, 2016), the effect of internal weather events on country-scale production quantities in Argentina still remain as a question. Therefore, the methodology presented in this study provides the first step to provide an answer to that question. Moreover, despite its own singularities and limitations, the simplicity of the approach makes it easy to be applied to any country and any crop with limited information -all models are wrong, some are useful (Box, 1979)-.

The other limitation is concerning future forecasts. The approach is primarily a methodology of deconstructing the past, but it can be easily adapted as a predictive tool following a stochastic simulation approach. However, even if average production and international prices could be forecast, climate modeling and specially climate variability modeling remains a challenge. As it was said, South Eastern South America (SESA) is a region that has exhibited one of the largest wetting trends during the 20th Century (Barros, 2015; Gonzales, 2014). Climate models suggest that stratospheric ozone depletion results in a significant wetting of SESA over the period 1960-1999 (Gonzales, 2014; Barros, 2015). Since the ozone layer is predicted to recover, precipitation will stabilize or, possibly, decrease in the coming decades (Gonzales, 2014). However, this forecast does not include the incidence and recurrence of severe and extreme drought events, which were the cases presented in this study. As a result, a scenario simulation approach can be presented, which will be one of the main continuation of this line of research.

\section{Conclusions}

This paper has presented a simple approach to value past economic losses in soybean production due to cases of extreme or severe drought. Extreme deviations were analyzed and compared with the Palmer Drought Index and by means of the construction of counterfactual of a non-extreme variability scenario, production losses are monetized by means of the international soybean price.

The study was developed at a county level for the Provinces of Buenos Aires, Cordoba, Santa Fe, Entre Rios y La Pampa finding a coincidence between extreme negative deviation in yields and severe and extreme cases of droughts.

In the last 17 years, the agricultural campaigns of 2008/2009 and 2011/2012 suffered the greatest decreased in soybean yields at a county level. The total loss generated in those years was estimated in u\$s 8.046 million in 2016 dollars, amount that represents $22 \%$ of Argentinean's international reserves of 2016.

The objective of the estimation is to provide a general approximation of estimated income losses to have a first glance of the dimension of the phenomena, and therefore consider if there is any economic convenience of applying adaptation measures. The case analyzed provides a rapid approach and the magnitude of the estimation -which is conservative because it measures the loss relative to the one standard deviation and not to the mean- permits to conclude that cases of severe and extreme drought might increase macroeconomic risk due to dependence of soybean exports. 
Despite the fact that the methodology may have certain limitations, it provides an easy understandable approach to policy makers, it requires basic information and can be easily replicated to other crops. Nevertheless, the estimates must be considered as a starting point of discussion and not as a precise valuation, therefore more into detailed research has to be done depending the kind of adaptation measure to be implemented. For instance, this approach is not adequate to design an index based insurance; on the other hand, might provide insights to design macroeconomic and fiscal stabilization rules.

Future research on this area will complete estimates with the study of the reaction of crops to different levels of drought, as well as the incidence of other events such as excessive rainfall.

\section{References}

Adger, W. N. (2006). Vulnerability. Global Environmental Change, 16(3), pp. 268-281. doi:10.1016/j.gloenvcha.2006.02.006

Arteaga, C., Granados, J., \& Ojeda Joya, J. (2013). Determinantes de los precios internacionales de los bienes básicos. Ensayos sobre Política Económica. 31(71), 85-107. doi:10.1016/s0120-4483(13)70013-7

Baethgen, W. (2008). Gestión de riesgos climáticos y su adaptación a la agricultura. En http://www.caf.org.uy/Cambio-climatico-Dr-Baethgen

Baethgen, W.E. (2008). Climate Risk Management and Adaptation to Climate Change. In: Uruguay, Climate Change Here and Now. Suplementary document for the UNDP Report on Human Development. UNDP Uruguay, Montevideo.

Barros V. R., Boninsegna J. A., Camilloni I. A., Chidiak M., Magrín G. O. y Rusticucci M. (2015). Climate change in Argentina: trends, projections, impacts and adaptation. WIREs Clim Change, 6: 151-169. doi: 10.1002/wcc.316.

Barros V.; Vera C., Agosta E., Araneo D.; Camilloni I., Carril A. F., Doyle M.E., Frumento O., Nuñez M., Ortiz de Zárate M.I., Penalba O., Rusticucci M., Saulo C., Solman S. (2014). Tercera Comunicación Nacional Sobre Cambio Climático. Consejo Nacional de Investigaciones Científicas y Técnicas (CONICET). Buenos Aires, Argentina.

Berterretche M.; Chiara J. P. y Isoldi, A. (2013). Revisión, análisis y propuestas de metodologías para evaluar el impacto económico de eventos climáticos extremos sobre la actividad agrícola. Presentación en el taller: Sistematización de la información climática para su uso en el proceso de toma de decisiones, 6 y 7 de junio de 2013. Montevideo.

Burke, M., Hsiang, S., Migule, E. (2015). Global non-linear effect of temperature on economic production. Nature 527, pp: 235-239. doi: 10.1038/nature15725.

Canziani, O.F., Palutikof, J.P., Van Der Linden, P.J. and Hanson, C.E. Eds. (2007). Climate change 2007: Impacts, adaptation and vulnerability. Contribution of Working Group II to the Fourth Assessment Report of the Intergovernmental Panel on Climate Change. Cambridge: Cambridge University Press.

Carter, J. G., Cavan, G., Connelly, A., Guy, S., Handley, J., Kazmierczak, A. (2015). Climate change and the city: Building capacity for urban adaptation. Progress in Planning 95, 1-66. doi:10.1016/j.progress.2013.08.001

Cashin, P., Mohaddes, K., Raissi, M. (2015). Fair Weather or Foul? The Macroeconomic Effects of El Niño. IMF Working paper 15/89. doi:10.5089/9781475535495.001

Cashin, P., Mohaddes, K., Raissi, M., \& Raissi, M. (2014). The differential effects of oil demand and supply shocks on the global economy. Energy Economics. 44, 113-134. doi:10.1016/j.eneco.2014.03.014

CEPAL. (2010). Istmo Centroamericano: efectos del cambio climático sobre la agricultura. Sede Subregional en México. Recuperado de: http://www.cepal.org/es/sedes-y-oficinas/cepal-mexico

CEPAL. (2014). La economía del cambio climático en la Argentina. Primera aproximación. Impreso en Naciones Unidas. Santiago de Chile. Recuperado de: http://www.cepal.org/es/publicaciones/35901-la-economia-del-cambio-climatico-en-la-argentina-primera-aproximacion 
Chimeli, A. B., De Souza Filho, F. D. A., Holanda, M. C., \& Petterini, F. C. (2008). Forecasting the impacts of climate variability: lessons from the rainfed corn market in Ceará, Brazil. Environment and Development Economics. 13(02), 201-227. doi:10.1017/S1355770X07004172

CIER (2007). The US Economic Impacts of Climate Change and the Costs of Inaction. A Review and Assessment by the Center for Integrative Environmental Research (CIER) at the University of Maryland.

Deschenes, O., \& Greenstone, M. (2007). The economic impacts of climate change: evidence from agricultural output and random fluctuations in weather. The American Economic Review, 97(1), 354-385. doi: 10.1257/aer.97.1.354

DNPC BID (2014). Impactos económicos del cambio climático en Colombia. Síntesis. Bogotá, Colombia. Recuperado de: https://colaboracion.dnp.gov.co/CDT/Prensa/Impactos\%20Econ\%C3\%B3micos\%20de1\%20Cambio\%20 Climatico_Sintesis_Resumen\%20Ejecutivo.pdf

FMI (2015). The Commodities Roller Coaster. A Fiscal Framework for Uncertain Times. IMF Fiscal Monitor.

Gall, M. (2015). The suitability of disaster loss databases to measure loss and damage from climate change. International Journal of Global Warming, 8(2), 170-190. doi: 10.1504/IJGW.2015.071966

Gonzalez, P.; Polvani, L.; Seager, R.; Correa, G. (2014). Stratospheric ozone depletion: a key driver of recent precipitation trends in South Eastern South America. Climate Dynamics, 42(7), 1775-1792. doi:10.1007/s00382-013$1777-\mathrm{x}$

Heinzenknecht, G. (2011). Proyecto riesgo y seguro agropecuario. Oficina de Riesgo Agropecuario. Recovered from http://www.ora.gov.ar/informes/enso.pdf

Intergovernmental Panel on Climate Change (IPCC). (2014). Climate Change 2014 Synthesis Report. Recovered from: http://www.ipcc.ch/pdf/assessment-report/ar5/syr/SYR_AR5_FINAL_full.pdf

IPCC, 2014. Summary for policymakers. In: Field, C.B., Barros, V.R., Dokken, D.J., Mach, K.J., Mastrandrea, M.D., Bilir, T.E., Chatterjee, M., Ebi, K.L., Estrada, Y.O., Genova, R.C., Girma, B., Kissel, E.S., Levy, A.N., MacCracken, S., Mastrandrea, P.R., White, L.L. (Eds.), Climate Change 2014: Impacts, Adaptation, and Vulnerability. Part A: Global and Sectoral Aspects. Contribution of Working Group II to the Fifth Assessment Report of the Intergovernmental Panel on Climate Change. Cambridge University Press, Cambridge, United Kingdom and New York, NY, USA, pp. 1-32.

Irwin, S., \& Good, D. (2015). Forming Expectations for the 2015 US Average Soybean Yield: What Does History Teach Us?. Farmdoc daily (5): 51. Department of Agricultural and Consumer Economics, University of Illinois at Urbana-Champaign.

Jeremy G. Carter, Gina Cavan, Angela Connelly, Simon Guy, John Handley, Aleksandra Kazmierczak (2015). Climate change and the city: Building capacity for urban adaptation. Progress in Planning 95, 1-66. doi:10.1016/j. progress.2013.08.001

Letson, David, Carlos E. Laciana, Federico E. Bert, Elke U. Weber, Richard W. Katz, Xavier I. Gonzalez, and Guillermo P. Podestá (2009). "Value of perfect ENSO phase predictions for agriculture: evaluating the impact of land tenure and decision objectives." Climatic Change 97(1-2): 145-170. doi:10.1007/s10584-009-9600-8

Letson, David, Guillermo P. Podestá, Carlos D. Messina, and R. Andrés Ferreyra (2005). "The uncertain value of perfect ENSO phase forecasts: stochastic agricultural prices and intra-phase climatic variations." Climatic Change 69(2-3): 163-196. doi:10.1007/s10584-005-1814-9

Lobell, D. B., \& Burke, M. B. (2010). On the use of statistical models to predict crop yield responses to climate change. Agricultural and Forest Meteorology, 150(11), 1443-1452. doi: 10.1016/j.agrformet.2010.07.008.

Lozanoff, J. y Cap E. (2006). El impacto del cambio climático sobre la agricultura Argentina: Un estudio económico. Buenos Aires. Argentina. INTA.

Massot, J., Baez, G., Prieto, K., Petri, G., Argüero, L., Thomasz, E., Gayá, R., Fusco, M. (2016). Agroindustria, innovación y crecimiento económico en la Argentina. Ed.: EDICON. In Spanish.

Mendelsohn, R., Dinar A.y Sanghi A. (2001), The Effect of Development on the Climate Sensitivity of Agriculture, Environment and Development Economics, 6:85-101. doi:10.1017/s1355770x01000055

Moser, S. C., \& Ekstrom, J. A. (2010). A framework to diagnose barriers to climate change adaptation. Proceedings of the National Academy of Sciences, 107(51), 22026-22031. doi:10.1073/pnas.1007887107 
Murgida A. M., Travasso M. I., González S. y Rodríguez G. R. (2014). Evaluación de impactos del cambio climático sobre la producción agrícola en la Argentina. Serie medio ambiente y desarrollo. No. 155. Naciones Unidas. Santiago de Chile, Chile.

Natenzon, C. (2014). Vulnerabilidad social, amenaza y riesgo frente al cambio climático. Tercera Comunicación Nacional de la República Argentina a la Convención Marco de las Naciones Unidas sobre Cambio Climático.

OCDE/CEPAL/CAF (2015), Perspectivas económicas de América Latina 2016: Hacia una nueva asociación con China, OECD Publishing, Paris.

Ordaz, J. L., Ramírez, D., Mora, J., Acosta, A., \& Serna, B. (2010). Costa Rica: efectos del cambio climático sobre la agricultura. CEPAL, México DF.

Ortiz de Zarate, M. J., Ramayon, J. J. y Rolla, A. L. (2014). Agricultura y Ganadería impacto y vulnerabilidad al cambio climático. Posibles medidas de adaptación. 3era comunicación nacional de la República Argentina a la Convención Marco de las Naciones Unidas sobre cambio climático.

Paltasingh, K. R., Goyari, P., \& Mishra, R. K. (2012). Measuring weather impact on crop yield using aridity index: Evidence from Odisha. Agricultural Economics Research Review, 25(2), 205-216.

Podestá, G., Letson, D., Messina, C., Royce, F., Ferreyra, R. A., Jones, J., ... O’Brien, J. J. (2002). Use of ENSO-related climate information in agricultural decision making in Argentina: a pilot experience. Agricultural Systems, 74(3), 371-392. doi:10.1016/s0308-521x(02)00046-x

Podestá, G. P., Natenzon, C. E., Hidalgo, C., \& Ruiz Toranzo, F. (2013). Interdisciplinary production of knowledge with participation of stakeholders: A case study of a collaborative project on climate variability, human decisions and agricultural ecosystems in the Argentine Pampas. Environmental Science \& Policy, 26, 40-48. doi:10.1016/j. envsci.2012.07.008

Rahman, M. S., Huq, M. M., Sumi, A., Mostafa, M. G., \& Azad, M. R. (2005) Statistical Analysis of Crop-Weather Regression Model for Forecasting Production Impact of Aus Rice in Bangladesh. International Journal of Statistical Sciences. Vol 4, pp 57-77.

Ramírez D., Ordaz L., Mora J. y Acosta A. (2010). La economía del cambio climático en Centroamérica. Comisión Económica para América Latina (CEPAL), sede subregional en México.

Revi, A., Satterthwaite, D. E., Aragón-Durand, F., Corfee-Morlot, J., Kiunsi, R. B., Pelling, M., \& Solecki, W. (2014). Urban areas. Climate change, 535-612.

Rosenzweig, C., Solecki, W. D., Blake, R., Bowman, M., Faris, C., Gornitz, V., Horton, R., Klaus, J., LeBlanc, A., Leichenko, R., Linkin, M., Major, D., O’Grady, M., Patrick, L., Sussman, E., Yohe, G. \& Zimmerman, R. (2011). Developing coastal adaptation to climate change in the New York City infrastructure-shed: process, approach, tools, and strategies. Climatic Change, 106(1), 93-127. doi: 10.1007/s10584-010-0002-8

Schaechter,A., Kinda, T., Budina, N., Weber, A. (2012). Fiscal Rules in Response to the Crisis-Toward the "Next-Generation" Rules. A New Dataset. IMF Working Paper 12/187. doi:10.5089/9781475505351.001

Schlenker Wolfram, Hanemann W. Michael, and Fisher Anthony C. (2006). The Impact of Global Warming on U.S. Agriculture: An Econometric Analysis of Optimal Growing Conditions. Review of Economics and Statistics, 88(1): 113-25. doi:10.1162/rest.2006.88.1.113

Seaman, J., Sawdon, G., Acidri, J., Petty, C. (2014). The Household Economy Approach. Managing the impact of climate change on poverty and food security in developing countries. Climate Risk Management 4-5, 59-68. doi:10.1016/j.crm.2014.10.001

Seo, S. N. y Mendelsohn R. (2008a). A Ricardian analysis of the impact of climate change on Latin American farms. Policy Research Series Working Paper, $N^{\circ} 4163$, Washington, D. C., Banco Mundial.

Seo, S. N. \& Mendelsohn R. (2008b), A Ricardian analysis of the impact of climate change on South American farms", Chilean Journal of Agricultural Research, 68(1). p.p. 69-79.

Seo, S. N. \& Mendelsohn R. (2008c), An analysis of crop choice: Adapting to climate change in Latin American Farms. Ecological Economics, 67,109-116.

Seo, S. N. \& Mendelsohn R. (2008d), Measuring impacts and adaptations to climate change: A structural Ricardian model of African Livestock Management, Agricultural Economics, 38. p.p. 151-165.

Susskind, L., Rumore, D. L., Hulet, C., \& Field, P. (2015). Managing climate risks in coastal communities: strategies for engagement, readiness and adaptation. London; New York, NY: Anthem Press. doi:10.2307/j.ctt1gxp7qz 
Tannura, M.A., S.H. Irwin, and D.L. Good. "Weather, Technology, and Corn and Soybean Yields in the U.S. Corn Belt.” Marketing and Outlook Research Report 2008-01, Department of Agricultural and Consumer Economics, University of Illinois at Urbana-Champaign, February 2008.

Thomasz, E.; Massot, J.; Rondinone, G. (2016). Is the interest rate more important than stocks? The case of agricultural commodities in the context of the financialization process. Revista Lecturas de Economía, N 85, Universidad de Antioquia. doi:10.17533/udea.le.n85a04 
Appendix A: Regression of each county analyzed

\begin{tabular}{|c|c|c|c|c|c|}
\hline Buenos Aires & Slope & Intercept & Cordoba & Slope & Intercept. \\
\hline 25 de Mayo & 0.040 & 1.327 & Calamuchita & 0.031 & 1.750 \\
\hline 9 de Julio & 0.051 & 1.164 & Colon & 0.036 & 1.793 \\
\hline Adolfo Alsina & 0.018 & 1.124 & General Roca & 0.040 & 1.418 \\
\hline Adolfo G. Chaves & 0.006 & 1.341 & General San Martin & 0.030 & 1.406 \\
\hline Alberti & 0.044 & 1.256 & Juarez Celman & 0.025 & 1.493 \\
\hline Arrecifes & 0.045 & 1.404 & Marcos Juarez & 0.051 & 1.485 \\
\hline Ayacucho & 0.039 & 1.276 & P. R. Saenz Pena & 0.040 & 1.415 \\
\hline Azul & -0.002 & 1.990 & Rio Cuarto & 0.023 & 1.530 \\
\hline Balcarce & 0.005 & 1.827 & Rio Primero & 0.026 & 1.770 \\
\hline Baradero & 0.045 & 1.440 & Río Seco & 0.006 & 1.914 \\
\hline Benito Juarez & 0.013 & 1.569 & Rio Segundo & 0.027 & 1.531 \\
\hline Bolivar & 0.036 & 1.322 & San Justo & 0.027 & 1.697 \\
\hline Bragado & 0.047 & 1.271 & Santa Maria & 0.025 & 1.542 \\
\hline Brandsen & 0.036 & 1.257 & Tercero Arriba & 0.031 & 1.412 \\
\hline Campana & 0.057 & 0.989 & Totoral & 0.027 & 1.920 \\
\hline Canuelas & 0.041 & 1.418 & Tulumba & -0.012 & 2.127 \\
\hline Capitan Sarmiento & 0.049 & 1.254 & Union & 0.042 & 1.482 \\
\hline Carlos Casares & 0.042 & 1.178 & & & \\
\hline Carlos Tejedor & 0.042 & 1.029 & Santa Fe & Slope & Intercept \\
\hline Carmen de Areco & 0.051 & 1.453 & 9 de Julio & 0.021 & 1.367 \\
\hline Castelli & 0.056 & 1.638 & Belgrano & 0.042 & 1.593 \\
\hline Chacabuco & 0.052 & 1.434 & Caseros & 0.046 & 1.444 \\
\hline Chascomus & 0.046 & 1.386 & Castellanos & 0.042 & 1.350 \\
\hline Chivilcoy & 0.045 & 1.215 & Constitución & 0.043 & 1.527 \\
\hline Colon & 0.059 & 1.256 & General Lopez & 0.048 & 1.367 \\
\hline Coronel Dorrego & 0.007 & 1.042 & General Obligado & 0.009 & 1.441 \\
\hline Coronel Pringles & -0.006 & 1.490 & Iriondo & 0.046 & 1.465 \\
\hline Coronel Suarez & 0.024 & 1.224 & La Capital & 0.031 & 1.482 \\
\hline Daireaux & 0.036 & 1.252 & Las Colonias & 0.036 & 1.490 \\
\hline Dolores & 0.038 & 1.658 & Rosario & 0.040 & 1.532 \\
\hline Exaltación de la Cruz & 0.053 & 1.206 & San Cristobal & 0.031 & 1.353 \\
\hline Florentino Ameghino & 0.034 & 2.251 & San Javier & 0.011 & 1.458 \\
\hline General Alvarado & 0.007 & 1.728 & San Jeronimo & 0.042 & 1.512 \\
\hline General Alvear & 0.026 & 1.658 & San Justo & 0.020 & 1.755 \\
\hline General Arenales & 0.060 & 1.220 & San Lorenzo & 0.045 & 1.452 \\
\hline General Belgrano & 0.040 & 1.377 & San Martin & 0.052 & 1.304 \\
\hline General Guido & -0.190 & 2.519 & Vera & 0.019 & 1.292 \\
\hline
\end{tabular}




\begin{tabular}{|c|c|c|c|c|c|}
\hline General J. Madariaga & 0.063 & 1.331 & & & \\
\hline General La Madrid & 0.018 & 1.419 & La Pampa & Slope & Intercept \\
\hline General Las Heras & 0.056 & 1.745 & Atreuco & -0.003 & 1.426 \\
\hline General Lavalle & 0.025 & 2.617 & Capital & 0.001 & 1.409 \\
\hline General Paz & 0.040 & 1.288 & Catriló & 0.017 & 1.135 \\
\hline General Pinto & 0.051 & 1.141 & Chapaleufu & 0.037 & 1.418 \\
\hline General Pueyrredon & 0.013 & 1.544 & Conhelo & 0.001 & 1.464 \\
\hline General Rodriguez & 0.062 & 1.410 & Guatrache & -0.015 & 1.254 \\
\hline General Viamonte & 0.051 & 1.276 & Maraco & 0.037 & 1.303 \\
\hline General Villegas & 0.045 & 1.154 & Quemu Quemu & 0.029 & 1.325 \\
\hline Guamini & 0.038 & 0.967 & Rancul & -0.004 & 1.732 \\
\hline Hipolito Yrigoyen & 0.030 & 1.483 & Realico & 0.018 & 1.352 \\
\hline Junin & 0.050 & 1.305 & Toay & 0.027 & 0.558 \\
\hline Laprida & -0.007 & 1.746 & Trenel & 0.009 & 1.309 \\
\hline Las Flores & 0.045 & 1.231 & Utracan & 0.006 & 0.885 \\
\hline Leandro N. Alem & 0.053 & 1.282 & & & \\
\hline Lincoln & 0.050 & 1.113 & Entre Rios & Slope & Intercept \\
\hline Loberia & 0.002 & 1.727 & Colon & 0.024 & 1.809 \\
\hline Lobos & 0.044 & 1.259 & Concordia & 0.018 & 2.140 \\
\hline Lujan & 0.055 & 1.331 & Diamante & 0.030 & 2.213 \\
\hline Magdalena & 0.036 & 1.442 & Federacion & 0.023 & 1.999 \\
\hline Maipu & 0.032 & 1.516 & Federal & 0.028 & 2.002 \\
\hline Mar Chiquita & 0.052 & 1.933 & Feliciano & 0.041 & 1.769 \\
\hline Marcos Paz & 0.071 & 1.214 & Gualeguay & 0.027 & 2.126 \\
\hline Mercedes & 0.033 & 1.526 & Gualeguaychu & 0.038 & 1.817 \\
\hline Monte & 0.040 & 1.224 & $\mathrm{La} \mathrm{Paz}$ & 0.033 & 2.108 \\
\hline Navarro & 0.046 & 1.326 & Nogoya & 0.037 & 1.774 \\
\hline Necochea & 0.024 & 1.224 & Parana & 0.035 & 2.119 \\
\hline Olavarria & 0.020 & 1.535 & San Salvador & 0.050 & 1.809 \\
\hline Patagones & -0.002 & 1.773 & Tala & 0.032 & 1.750 \\
\hline Pehuajo & 0.038 & 1.262 & Uruguay & 0.036 & 1.835 \\
\hline Pellegrini & 0.027 & 1.205 & Victoria & 0.030 & 2.170 \\
\hline Pergamino & 0.054 & 1.353 & Villaguay & 0.023 & 1.848 \\
\hline Pila & 0.025 & 1.604 & & & \\
\hline Pilar & 0.051 & 1.337 & & & \\
\hline Puan & 0.005 & 1.171 & & & \\
\hline Ramallo & 0.049 & 1.402 & & & \\
\hline Rauch & 0.031 & 0.939 & & & \\
\hline
\end{tabular}




\begin{tabular}{lll}
\hline Rivadavia & 0.041 & 1.220 \\
Rojas & 0.054 & 1.237 \\
Roque Perez & 0.048 & 1.061 \\
Saavedra & 0.015 & 1.294 \\
Saladillo & 0.045 & 1.181 \\
Salliquelo & 0.022 & 1.272 \\
Salto & 0.053 & 1.368 \\
San Andres de Giles & 0.053 & 1.181 \\
San Antonio de Areco & 0.049 & 1.315 \\
San Cayetano & 0.019 & 0.915 \\
San Nicolas & 0.050 & 1.355 \\
San Pedro & 0.047 & 1.346 \\
San Vicente & 0.043 & 1.357 \\
Suipacha & 0.030 & 1.337 \\
Tandil & 0.018 & 1.498 \\
Tapalque & 0.007 & 1.988 \\
Tordillo & -0.15 & 2.517 \\
Tornquist & 0.009 & 1.225 \\
Trenque Lauquen & 0.055 & 1.320 \\
Tres Arroyos & 0.022 & 0.995 \\
Tres Lomas & 0.029 & 1.845 \\
Villarino & 0.016 & 1.184 \\
Zarate & 0.047 & 1.300 \\
\hline
\end{tabular}

Source: own elaboration 